\title{
Cross Compatibility between Eggplant (Solanum melongena L.) and Wild Relatives
}

\author{
Mohammad Ali and Kunimitsu Fujieda \\ Faculty of Agriculture, Kyushu University, Hakozaki, Higashi-ku, Fukuoka 812
}

\begin{abstract}
Summary
Pollen tube growth behavior and success of interspecific crosses between eggplant and wild relatives were studied. Solanum gilo, $S$. insanum and $S$. integrifolium were found compatible to eggplant. $S$. indicum, as the male and female parent, produced mostly unfilled seeds with eggplant 'Senryo 2 gou'. This species as seed parent produced about $50 \%$ filled seeds when it was pollinated by eggplant 'Uttara'. Only pollination by 'Senryo 2 gou' produced a few viable seeds on $S$. surattense and $S$. xanthocarpum. Pollen tubes of $S$. mammosum grew normally in the pistils of 'Senryo 2 gou' resulting $100 \%$ parthenocarpic fruit development. The 'Uttara' produced no parthenocarpic fruit, while the former cultivar produced parthenocarpic fruit with 8 different species. Failure or poor germination of pollen, retarded growth of pollen tubes, termination of pollen tube growth before reaching the ovary, weak fluorescence of the pollen tubes, irregular deposition and size of callose plugs, swollen and/or branched pollen tube apex alone or in combination were observed in most of the incompatible crosses.
\end{abstract}

\section{Introduction}

Eggplant is susceptible to several soil borne diseases and insect pests. Some of the poor quality fruited cultivars and many related species of Solanum have partial to complete resistance against these hazardous pests $(1,5$, $9,10,19)$. There are several promising Solanum species which can directly be used as root stock for eggplant cultivation or as breeding materials. The use of interspecific hybrid, having multiple disease resistance as root stock might have immense importance. Some sporadic attempts were made to establish species relationship and to transfer desired gene(s) from wild to cultivated melongena $(2,6,9,11$, 13). In most of the earlier attempts, the number of species studied and/or the number of crosses made for each interspecific combination were poor. However, there are some arguable results of interspecific cross between eggplant and wild relatives $(6,12,17)$. Reports on interspecific compatibility in relation to

Received for publication August 26, 1989.

Part of this study was presented at the annual meeting of the Japanese Society for Horticultural Science, Tokyo, April, 1989. pollen tube growth and seed set in eggplant relatives are meager. Moreover, pollen tube growth behavior in interspecific crosses has not yet been reported. Interspecific compatibility in Solanum species in relation to pollen tube growth behavior and seed setting ability was examined in this study aiming at producing hybrid plants.

\section{Materials and Methods}

Two cultivars of eggplant, 'Senryo 2 gou' (an $F_{1}$ hybrid from Japan) and 'Uttara' (a purebred from Bangladesh), and 17 wild relatives (Table 1) were grown in vinyl house during 1987 and '88 at the University farm, Kyushu University. Direct and reciprocal crosses between eggplant and wild retatives were made from April to July 1988 through bud pollination. Throughout the hybridization period the minimum temperature was maintained at $16^{\circ} \mathrm{C}$ and the maximum at $27^{\circ} \mathrm{C}$. For the study of pollen tube growth behavior, pollinated pistils were collected after 3 days of pollination in acetic-alcohol $(1: 3 \mathrm{v} / \mathrm{v})$ for 24 $\mathrm{h}$, and transferred into $70 \%$ ethanol for a day or long. Pistils of most of the species were softened at $60^{\circ} \mathrm{C}$ for $60 \mathrm{~min}$ in $1 \mathrm{~N} \mathrm{NaOH}$. 
Table 1. Pollen tube behavior in the pistils in self and interspecific crosses of Solanum.

\begin{tabular}{|c|c|c|c|c|c|c|c|c|c|c|c|c|}
\hline \multirow[b]{3}{*}{ Species } & & & & & \multicolumn{8}{|c|}{ As pistilate parent } \\
\hline & \multicolumn{4}{|c|}{ Self } & \multicolumn{4}{|c|}{ 'Senryo 2 gou' } & \multicolumn{3}{|c|}{ 'Uttara' } & \multirow[b]{2}{*}{4} \\
\hline & 1 & 2 & 3 & $4^{z}$ & 1 & 2 & 3 & 4 & 1 & 2 & 3 & \\
\hline \multicolumn{13}{|l|}{ S. melongena L. } \\
\hline 'Senryo 2 gou' & $\mathrm{M}$ & $\mathrm{N}$ & $\mathrm{N}$ & $\mathrm{N}^{\mathrm{y}}$ & & & & & & & & \\
\hline 'Uttara' & M & $\mathrm{N}$ & $\mathrm{N}$ & $\mathrm{N}$ & & & & & & & & \\
\hline S. achrolcucum Bast. & M & $\mathrm{N}$ & $\mathrm{N}$ & $\mathrm{N}$ & $\mathrm{F}$ & $\mathrm{W}$ & - & - & $\mathrm{M}$ & $\mathrm{W}$ & - & - \\
\hline S. ferox $\mathrm{L}$. & $\mathrm{F}$ & $\mathrm{N}$ & $\mathrm{N}$ & $\mathrm{N}+\mathrm{A}$ & $\mathrm{F}$ & $\mathrm{N}$ & $\mathrm{N}+\mathrm{S}$ & $N+A$ & $M+F$ & $\mathrm{~N}$ & $\mathrm{~N}+\mathrm{S}$ & $\mathrm{N}+\mathrm{A}$ \\
\hline S. gilo Raddi. & $\mathrm{M}$ & $\mathrm{N}$ & $\mathrm{N}$ & $\mathrm{N}$ & $\mathrm{M}$ & $\mathrm{N}$ & $\mathrm{N}$ & $\mathrm{N}$ & $\mathrm{M}$ & $\mathrm{N}$ & $\mathrm{N}$ & $\mathrm{N}$ \\
\hline S. indicum L. & $\mathrm{F}$ & $\mathrm{N}$ & $\mathrm{N}$ & $\mathrm{N}$ & $\mathrm{M}$ & $\mathrm{N}$ & $\mathrm{N}$ & $\mathrm{N}$ & $\mathrm{M}$ & $\mathrm{N}$ & $\mathrm{N}$ & $\mathrm{N}$ \\
\hline S. insanum L. & $\mathrm{M}$ & $\mathrm{N}$ & $\mathrm{N}$ & $\mathrm{N}$ & $\mathrm{M}$ & $\mathrm{N}$ & $\mathrm{N}$ & $\mathrm{N}$ & $\mathrm{M}$ & $\mathrm{N}$ & $\mathrm{N}$ & $\mathrm{N}$ \\
\hline S. integrifolium Poir. & $\mathrm{M}$ & $\mathrm{N}$ & $\mathrm{N}$ & $\mathrm{N}$ & $\mathrm{M}$ & $\mathrm{N}$ & $\mathrm{N}$ & $\mathrm{N}+\mathrm{A}$ & $\mathrm{M}$ & $\mathrm{N}$ & $\mathrm{N}$ & $\mathrm{N}$ \\
\hline S. khasianum Clarke. & $\mathrm{M}$ & $\mathrm{N}$ & $\mathrm{N}$ & $\mathrm{N}$ & $\mathrm{M}$ & $\mathrm{N}$ & $N+B S$ & $\mathrm{~N}+\mathrm{A}$ & $\mathrm{M}$ & $\mathrm{N}$ & $\mathrm{N}+\mathrm{S}$ & $\mathrm{N}+\mathrm{A}$ \\
\hline S. mammosum L. & M & $\mathrm{N}$ & $\mathrm{N}$ & $\mathrm{N}$ & $\mathrm{M}$ & $\mathrm{N}$ & $\mathrm{N}$ & $\mathrm{N}$ & $\mathrm{M}$ & $\mathrm{N}$ & $\mathrm{N}$ & $\mathrm{N}$ \\
\hline S. nigrum L. & $\mathrm{M}$ & $\mathrm{N}$ & $\mathrm{N}$ & $\mathrm{N}$ & $\mathrm{M}$ & W & $\mathrm{N}+\mathrm{S}$ & - & $\mathrm{M}$ & W & - & - \\
\hline S. nodiflorum Jacq. & $\mathrm{M}$ & $\mathrm{N}$ & $\mathrm{N}$ & $\mathrm{N}$ & - & - & - & - & $\mathrm{M}$ & W & - & - \\
\hline S. sisymbriifolium Lam. & M & $\mathrm{N}$ & $\mathrm{N}$ & $\mathrm{N}$ & $\mathrm{M}$ & $\mathrm{N}$ & $\mathrm{N}+\mathrm{BS}$ & A & $\mathrm{M}$ & $\mathrm{N}$ & $\mathrm{N}+\mathrm{S}$ & A \\
\hline S. surattense Burm. & M & $\mathrm{N}$ & $\mathrm{N}$ & $\mathrm{N}$ & $\mathrm{M}$ & $\mathrm{N}$ & $N+S$ & $\mathrm{~N}+\mathrm{A}$ & $\mathrm{M}$ & $\mathrm{N}$ & $\mathrm{N}+\mathrm{BS}$ & $\mathrm{N}+\mathrm{A}$ \\
\hline S. torvum Swartz. & $\mathrm{M}$ & $\mathrm{N}$ & $\mathrm{N}$ & $\mathrm{N}$ & $\mathrm{M}$ & $\mathrm{N}$ & $\mathrm{N}$ & $\mathrm{N}$ & $\mathrm{M}$ & $\mathrm{N}$ & $\mathrm{N}+\mathrm{S}$ & $\mathrm{N}$ \\
\hline S. toxicarium Lam. & $\mathrm{M}$ & $\mathrm{N}$ & $\mathrm{N}$ & $\mathrm{N}+\mathrm{A}$ & $\mathrm{M}$ & W & $\mathrm{B}$ & A & M & $\mathrm{N}$ & $\mathrm{N}+\mathrm{S}$ & $\mathrm{N}+\mathrm{A}$ \\
\hline S. verbascifolium $\mathrm{L}$. & $\mathrm{M}$ & $\mathrm{N}$ & $\mathrm{N}$ & $\mathrm{N}$ & $\mathrm{F}$ & $\mathrm{W}$ & - & A & $\mathrm{M}$ & W & - & - \\
\hline$S$. viarum Dunal. & $\mathrm{M}$ & $\mathrm{N}$ & $\mathrm{N}$ & $\mathrm{N}$ & $\mathrm{M}$ & $\mathrm{N}$ & $\mathrm{N}+\mathrm{S}$ & $\mathrm{N}+\mathrm{A}$ & $\mathrm{M}$ & $\mathrm{N}$ & $\mathrm{N}$ & $\mathrm{N}+\mathrm{A}$ \\
\hline S. xanthocarpum S. et W. & $\mathrm{M}$ & $\mathrm{N}$ & $\mathrm{N}$ & $\mathrm{N}$ & $\mathrm{M}$ & $\mathrm{N}$ & $\mathrm{S}$ & A & $\mathrm{M}$ & $\mathrm{N}$ & $\mathrm{N}$ & $\mathrm{N}$ \\
\hline \multicolumn{13}{|c|}{ As pollen parent } \\
\hline S. achrolcucum & & & & & $\mathrm{F}$ & $\mathrm{N}$ & - & - & $\mathrm{M}$ & $\mathrm{N}$ & $\mathrm{N}$ & $\mathrm{N}$ \\
\hline S. ferox & & & & & $\mathrm{F}$ & $\mathrm{N}$ & - & - & $\mathrm{F}$ & $\mathrm{N}$ & - & A \\
\hline S. gilo & & & & & $\mathrm{M}$ & $\mathrm{N}$ & $\mathrm{N}$ & $\mathrm{N}$ & $\mathrm{M}$ & $\mathrm{N}$ & $\mathrm{N}$ & $\mathrm{N}$ \\
\hline S. indicum & & & & & $\mathrm{M}$ & $\mathrm{N}$ & $\mathrm{N}$ & A & $\mathrm{M}$ & $\mathrm{N}$ & $\mathrm{N}$ & $\mathrm{N}$ \\
\hline S. insanum & & & & & $\mathrm{M}$ & $\mathrm{N}$ & $\mathrm{N}$ & $\mathrm{N}$ & M & $\mathrm{N}$ & $\mathrm{N}$ & $\mathrm{N}$ \\
\hline S. integrifolium & & & & & $\mathrm{F}$ & $\mathrm{N}$ & $\mathrm{N}$ & $N+A$ & $M+F$ & $\mathrm{~N}$ & $\mathrm{~N}$ & $\mathrm{~N}$ \\
\hline S. khasianum & & & & & $\mathrm{F}$ & $\mathrm{N}$ & - & - & $\mathrm{F}$ & $\mathrm{N}$ & - & - \\
\hline S. mammosum & & & & & $\mathrm{F}$ & $\mathrm{N}$ & - & - & $\mathrm{M}$ & $\mathrm{N}$ & $\mathrm{N}$ & $\mathrm{N}$ \\
\hline S. nigrum & & & & & $\mathrm{F}$ & $\mathrm{N}$ & - & - & $\mathrm{F}$ & $\mathrm{W}$ & BS & - \\
\hline S. nodiflorum & & & & & $\mathrm{F}$ & $\mathrm{N}$ & $\mathrm{N}+\mathrm{S}$ & A & $\mathrm{F}$ & $\mathrm{N}$ & $\mathrm{N}+\mathrm{S}$ & A \\
\hline S. sisymbriifolium & & & & & $\mathrm{M}$ & $\mathrm{N}$ & - & - & $\mathrm{M}$ & $\mathrm{N}$ & $\mathrm{N}+\mathrm{S}$ & - \\
\hline S. surattense & & & & & $M+F$ & $\mathrm{~N}$ & $\mathrm{~N}$ & $\mathrm{~N}+\mathrm{A}$ & $\mathrm{M}$ & $\mathrm{N}$ & $\mathrm{N}$ & $\mathrm{N}$ \\
\hline S. torvum & & & & & $\mathrm{F}$ & $\mathrm{N}$ & - & - & $\mathrm{F}$ & $\mathrm{N}$ & $\mathrm{N}$ & $\mathrm{N}$ \\
\hline S. toxicarium & & & & & $\mathrm{M}$ & $\mathrm{N}$ & - & - & $\mathrm{M}$ & $\mathrm{N}$ & - & - \\
\hline S. verbascifolium & & & & & $\mathrm{F}$ & $\mathrm{N}$ & - & - & $\mathrm{F}$ & $\mathrm{W}$ & - & - \\
\hline S. viarum & & & & & $\mathrm{F}$ & W & - & - & $\mathrm{F}$ & $\mathrm{N}$ & - & - \\
\hline S. xanthocarpum & & & & & $\mathrm{M}$ & $\mathrm{N}$ & $\mathrm{N}$ & $\mathrm{N}$ & $\mathrm{M}$ & W & $\mathrm{N}$ & - \\
\hline
\end{tabular}

z 1 =Quantity of pollen germinated; $2=$ Fluorescent reaction; $3=$ Behavior of pollen tube apex; and $4=$ Behavior of callose plug.

y A=abnormal. B=branched. $\mathrm{F}$ =few. $\mathrm{M}=$ many. $\mathrm{N}$ =normal. $\mathrm{S}$ =swollen. $\mathrm{W}=$ weak. $\quad-=$ unable to be ascertained.

They were stained by $0.1 \%$ aniline blue(7) at least for $15 \mathrm{~min}$, squashed and observed under a fluorescent microscope (wave length $365 \mathrm{~nm}$ ). Quantity of pollen germinated and pollen tube growth through different parts of pistil, fluorescent reaction, pollen tube tip appearance and callose plug formation and dis- tribution pattern were recorded. Small callose deposition with equidistant distribution of the plugs throughout the pollen tube were considered as normal. Where pollen tube growth was limited on the stigma and/or fluorescent reaction was weak appearance of pollen tube apex and behavior of callose plugs could not 

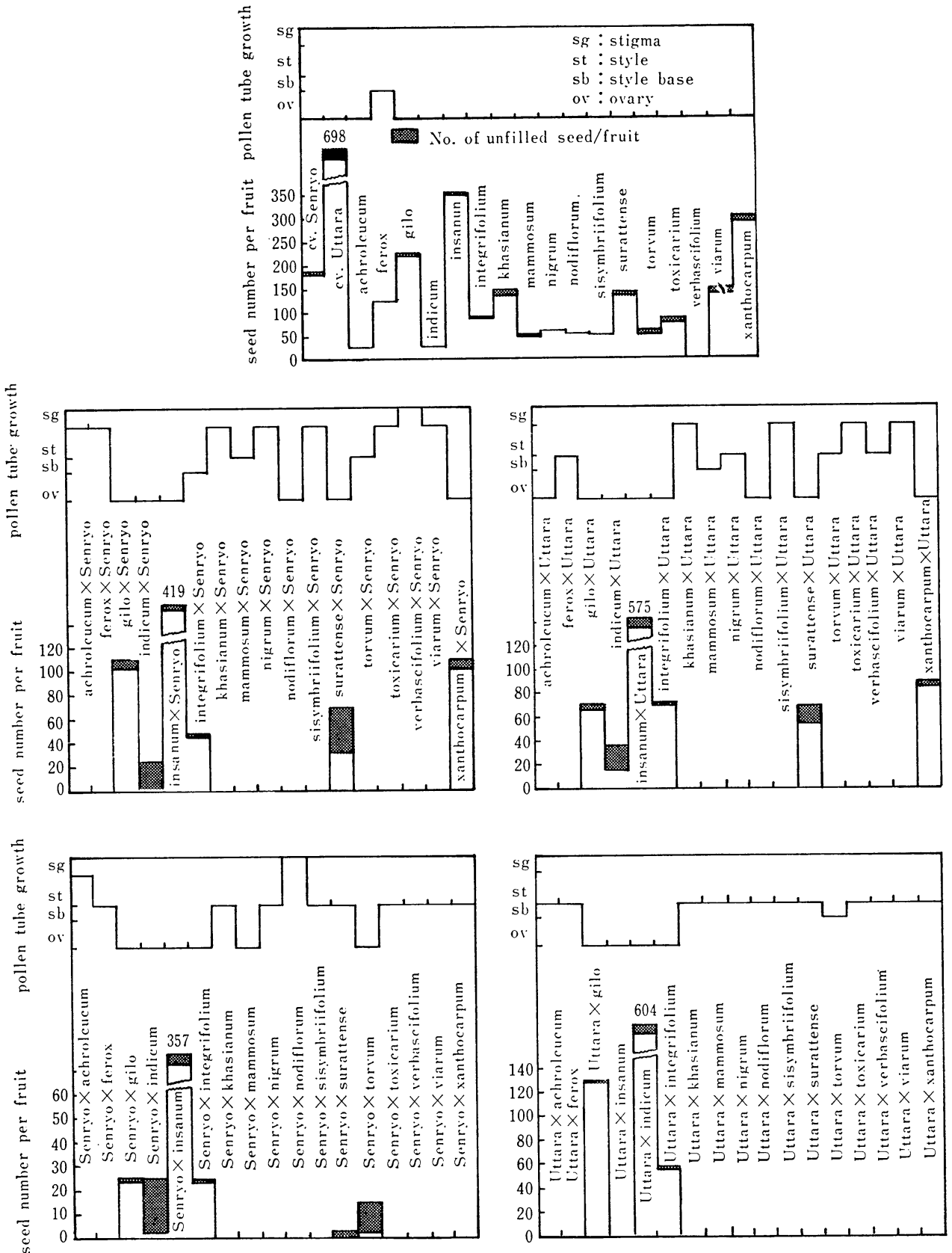

Fig. 1. Relationship between pollen tube growth in the pistil and seed set per fruit in selfing and interspecific crosses of Solanum.

be recorded in most of the cases. Nine to 15 observations were made per combination.

Fruit were harvested at maturity after 50 to 60 days of crossing except $S$. torvum which took 90 days. Immature and readily recognizable flat seeds and the seeds which floated on water were considered to be unfilled. The fruits which did not contain any seed were considered to be parthenocarpic. Number of filled and unfilled seeds per fruit were calculated on the total number of fruit set. Selfings were made as the control. Germination $\%$ of the $F_{1}$ seeds were evaluated in January ' 89 . Where there was very poor seed set, some of the seeds 
Table 2. Fruiting behavior of interspecific crosses between eggplant and wild relatives.

\begin{tabular}{|c|c|c|c|c|c|c|c|c|c|c|c|c|}
\hline \multirow[b]{3}{*}{ Species } & \multirow{2}{*}{\multicolumn{4}{|c|}{ Self }} & \multicolumn{8}{|c|}{ As pistilate parent } \\
\hline & & & & & \multicolumn{4}{|c|}{ 'Senryo 2 gou' } & \multicolumn{4}{|c|}{ 'Uttara' } \\
\hline & $\mathrm{NO}$ & FS & $\mathrm{PF}$ & $\mathrm{FW}^{2}$ & $\mathrm{NO}$ & FS & $\mathrm{PF}$ & FW & $\mathrm{NO}$ & FS & $\mathrm{PF}$ & FW \\
\hline \multicolumn{13}{|l|}{ S. melongena } \\
\hline 'Senryo 2 gou' & 15 & 87 & 0 & 247.1 & & & & & & & & \\
\hline 'Uttara' & 15 & 87 & 0 & 98.5 & & & & & & & & \\
\hline S. achrolcucum & 15 & 87 & 0 & 0.4 & 15 & 0 & 0 & - & 15 & 0 & 0 & 一 \\
\hline S. ferox & 15 & 27 & 0 & 5.3 & 15 & 47 & 100 & 32.6 & 15 & 0 & 0 & - \\
\hline S. gilo & 20 & 80 & 0 & 15.8 & 15 & 40 & 0 & 98.1 & 16 & 13 & 0 & 52.3 \\
\hline S. indicum & 15 & 100 & 0 & 0.6 & 15 & 80 & 17 & 107.1 & 15 & 0 & 0 & - \\
\hline S. insanum & 15 & 93 & 0 & 29.8 & 15 & 100 & 0 & 298.9 & 15 & 87 & 0 & 158.1 \\
\hline S. integriflium & 15 & 80 & 0 & 20.4 & 15 & 73 & 0 & 120.8 & 15 & 47 & 0 & 63.0 \\
\hline S. khasianum & 15 & 93 & 0 & 7.5 & 15 & 60 & 100 & 44.8 & 15 & 0 & 0 & - \\
\hline S. mammosum & 18 & 89 & 0 & 39.7 & 15 & 60 & 100 & 136.8 & 15 & 0 & 0 & - \\
\hline S. nigrum & 15 & 93 & 0 & 0.4 & 15 & 0 & 0 & - & 15 & 0 & 0 & - \\
\hline S. nodiflorum & 18 & 89 & 0 & 0.3 & 15 & 0 & 0 & - & 15 & 0 & 0 & - \\
\hline S. sisymbriifolium & 15 & 60 & 0 & 1.2 & 15 & 67 & 100 & 68.4 & 15 & 0 & 0 & - \\
\hline S. surattense & 15 & 93 & 0 & 3.1 & 15 & 67 & 70 & 95.6 & 15 & 0 & 0 & - \\
\hline S. torvum & 15 & 7 & 0 & 1.0 & 15 & 40 & 17 & 87.7 & 15 & 0 & 0 & - \\
\hline S. toxicarium & 15 & 87 & 0 & 1.3 & 15 & 0 & 0 & - & 15 & 0 & 0 & - \\
\hline S. verbascifolium & 15 & 0 & 0 & - & 15 & 47 & 100 & 123.3 & 15 & 0 & 0 & - \\
\hline S. viarum & 15 & 93 & 0 & 5.6 & 15 & 0 & 0 & - & 15 & 0 & 0 & - \\
\hline \multirow[t]{2}{*}{ S. xanthocarpum } & 15 & 100 & 0 & 3.4 & 15 & 0 & 0 & - & 15 & 0 & 0 & - \\
\hline & & & & & \multicolumn{8}{|c|}{ As pollen parent } \\
\hline S. achrolcucum & & & & & 15 & 0 & 0 & - & 15 & 0 & 0 & - \\
\hline S. ferox & & & & & 15 & 0 & 0 & - & 15 & 0 & 0 & - \\
\hline S. gilo & & & & & 15 & 73 & 0 & 12.5 & 13 & 87 & 0 & 8.7 \\
\hline S. indicum & & & & & 35 & 71 & 0 & 0.4 & 31 & 100 & 0 & 0.8 \\
\hline S. insanum & & & & & 15 & 87 & 0 & 33.5 & 16 & 100 & 0 & 48.5 \\
\hline S. integrifolium & & & & & 31 & 71 & 9 & 20.4 & 30 & 80 & 7 & 20.4 \\
\hline S. khasianum & & & & & 15 & 0 & 0 & - & 15 & 0 & 0 & - \\
\hline S. mammosum & & & & & 15 & 60 & 100 & 10.5 & 15 & 60 & 100 & 13.0 \\
\hline S. nigrum & & & & & 15 & 0 & 0 & - & 15 & 0 & 0 & - \\
\hline S. nodiflorum & & & & & 15 & 0 & 0 & - & 15 & 0 & 0 & - \\
\hline S. sisymbriifolium & & & & & 15 & 0 & 0 & - & 15 & 0 & 0 & - \\
\hline S. surattense & & & & & 31 & 97 & 0 & 3.2 & 30 & 93 & 0 & 3.0 \\
\hline S. torvum & & & & & 15 & 0 & 0 & - & 15 & 0 & 0 & - \\
\hline S. toxicarium & & & & & 15 & 0 & 0 & - & 15 & 0 & 0 & - \\
\hline S. verbascifolium & & & & & 15 & 0 & 0 & - & 15 & 0 & 0 & - \\
\hline S. viarum & & & & & 15 & 0 & 0 & - & 15 & 0 & 0 & - \\
\hline S. xanthocarpum & & & & & 15 & 93 & 0 & 1.8 & 11 & 73 & 0 & 1.7 \\
\hline
\end{tabular}

${ }^{2} \mathrm{NO}=$ No. of observations; $\mathrm{FS}=$ Fruit set $(\%) ; \mathrm{PF}=$ Parthenocarpic fruit $(\%) ; \mathrm{FW}=$ Fruit weight $(\mathrm{g})$.

morphologically as good as possible were sorted out from the seed lot that was considered unfilled earlier for germination test. The seeds were treated by gibbrellic acid $\left(\mathrm{GA}_{3}, 100 \mathrm{ppm}\right)$ for $24 \mathrm{~h}$ at $25^{\circ} \mathrm{C}$ and sown in vermiculite maintained in a germinator having $25 \pm 5^{\circ} \mathrm{C}$. Record on germination of seeds was taken after 18 days of sowing. In Fig. 1 pollen germination and pollen tube growth in different parts of pistils were considered when pollen tube apex was observed in that particular part of the pistil in at least $1 / 3$ of the observations made.

\section{Results}

Pollen germination and pollen tube growth behavior

The results of pollen germination and pollen tube behavior have been summarized in Table 1. Pollen germination took place in almost 
all the combinations but differential growth of pollen tube was observed (Fig. 1). 'Uttara', both as the pollen and pistilate parent, was found better than 'Senryo 2 gou' in respect of quantity of pollen germination. Stigmas of $S$. melongena were more favorable to germinate pollen of wild Solanum than those of other species studied. Poor pollen germination and/ or weak fluorescence of pollen tubes were observed in the stigmas of $S$. achrolcucum, $S$. ferox, S. integrifolium, S. khasianum, $S$. mammosum, $S$. nigrum, $S$. nodiflorum, $S$. torvum, $S$. toxicarium, $S$. verbascifolium and $S$. viarum when they were pollinated by $S$. melongena or vice versa. Normal pollen tube tips(4), bright fluorescence of the tubes having normal collose plug formation and distribution (18) were observed in the crosses between eggplant and $S$. gilo, $S$. insanum and $S$. indicum irrespective of direction of the crosses. Pollen tube behavior of $S$. mammosum was normal in the pistils of $S$. melongena but in reciprocal direction cultivar difference was noticed. Pistils of 'Senryo 2 gou' was favorable for pollen tube growth behavior of $S$. torvum; S. xanthobarpum favored the pollen of 'Senryo 2 gou'. On the other hand pollen tubes of 'Uttara' exhibited normal growth behabior in the pistils of $S$. integrifolium, $S$. surattense and $S$. torvum, but as the pistilate parent, 'Uttara' was congenial for S. integrifolium and $S$. xanthocarpum. Swollen and branched pollen tube apex alone or in combination with normal tube tip in the same pistil were observed in about $50 \%$ of the interspecific combinations when eggplant was the pistilate parent. Cultivar difference in $S$. melongena and difference due to direction of the interspecific crosses in relation to pollen tube growth behavior were also conspicuous in many cases. Random distribution of callose plugs and irregular deposition of callose in the pollen tubes were observed mostly in the tubes having abnormal growth. On selfing, pollen tube growth behavior was normal in most of the aspects studied in almost all the species.

\section{Pollen tube growth and fruit set}

Pollen tubes of 15 species grew down to the style and of 6 species to the ovary of 'Senryo 2 gou' (Fig. 1) while fruit set was observed with 11 species combinations (Table 2). Pollen tubes of all the species entered into the style and of 4 species up to the ovary of 'Uttara' (Fig. 1), but fruiting was recorded with 3 species (Table 2) common to 'Senryo 2 gou' as well. In reciprocal crosses, both of the eggplant cultivars produced fruit on the same 7 species (Table 2). Eight species produced parthenocarpic fruit on 'Senryo 2 gou', while 'Uttara' produced none. In self pollination (Table 2) there was no parthenocarpic fruit development. S. insanum, as the male parent, produced bigger fruit on both the cultivars (Table 2) than that of respective self (Table 2).

Pollen tube growth and seed set

Successful pollen tube growth of $S$. gilo, $S$. insanum and $S$. integrifolium up to the ovary of $S$. melongena and vice versa resulted into production of good number of seeds per fruit (Fig. 1). The pollen tubes of S. indicum and $S$. torvum grew up to the ovary of 'Senryo 2 gou' but most of the seeds were unfilled. The former species as the seed parent showed cultivar difference in respect to seed set having about $50 \%$ filled seed when was crossed with 'Uttara'. S. initgrifolium as the seed parent produced 45 seeds per fruit when it was pollinated by 'Senryo 2 gou'; pollen tubes of which could not reach beyond the style base indicated rather slow rate of pollen tube growth. S. surattense and S. xanthocarpum as pistilate parents were found compatible to both of the cultivars. In case of self pollination pollen tubes grew down to the ovary in all species and seeds were produced except in $S$. verbascifolium. The highest number of seed per fruit was recorded in 'Uttara' (self) followed by the combinanations of $S$. melongena and $S$. insanum.

\section{Seed germination}

More than $80 \%$ germination of seeds was recorded in 12 different interspecific combinations (Table 3). Germination of $S$. surattense and $S$. xanthocarpum in combination with 'Senryo 2 gou' as the male was poor while with 'Uttara' it was nil. When $S$. indicum was pollinated by 'Senryo 2 gou' the seeds failed to germinate, while the seeds fertilized by 'Uttara' pollen had poor germination. Seeds of 'Senryo 2 gou' $\times S$. indicum had $8 \%$ germi- 
Table 3. Seed germination ( $\%$ ) of interspecific hybirds between $S$. melongenca ('Senryo 2 gou' and 'Uttara') and wild relatives.

\begin{tabular}{|c|c|c|c|c|}
\hline \multirow[b]{2}{*}{ Wild relatives } & \multicolumn{2}{|c|}{ As seed parent } & \multicolumn{2}{|c|}{ As pollen parent } \\
\hline & 'Senryo 2 gou' & 'Uttara' & 'Senryo 2 gou' & 'Uttara' \\
\hline S. achrolcucum & - & - & - & - \\
\hline S. ferox & - & - & - & - \\
\hline S. gilo & $100(40)^{2}$ & $99(80)$ & $88(80)$ & $86(80)$ \\
\hline$S$. indicum & $8(25)$ & - & $0(25)$ & $9(90)$ \\
\hline S. insanum & $98(50)$ & $90(50)$ & $98(50)$ & $100(50)$ \\
\hline S. integrifolium & $99(80)$ & $98(90)$ & $100(50)$ & $96(80)$ \\
\hline S. khasianum & - & - & - & - \\
\hline S. mammosum & - & - & - & - \\
\hline S. nigrum & - & - & - & - \\
\hline S. nodiflorum & - & - & - & - \\
\hline S. sisymbriifolium & - & - & - & - \\
\hline S. surattense & $20(10)$ & - & $34(50)$ & $0(25)$ \\
\hline S. torvum & $0(25)$ & - & - & - \\
\hline S. toxicarium & - & - & - & - \\
\hline S. verbascifolium & - & - & - & - \\
\hline S. viarum & - & - & - & - \\
\hline S. xanthocarpum & - & - & $12(90)$ & $0(90)$ \\
\hline
\end{tabular}

z Values in parenthesis are the number of seeds sown.

- No seed set in these combinations.

nation. The seeds produced in 'Senryo 2 gou' pollinated by $S$. torvum did not germinate.

\section{Discussion}

Interspecific incompatibility in conventional sexual process is resulted mostly either due to failure of pollen germination or anomalous pollen tube growth behavior $(3,4,14)$. In our present observation it appeared that retarded pollen tube growth, branched or swollen pollen tube tips, irregular deposition and distribution of callose plugs in the pollen tubes alone or in combination of these abnormalities might have resulted into incompatibility. In compatible crosses pollen tubes had thin-walled tips and regularly spaced callose plugs $(4,18)$.

Tatebe(17) and Khan et al.(6) reported contradictory results about the compatibility between $S$. melongena and $S$. integrifolium. However, the present investigation conforms the results of Ludilov(8) and Nishio et al.(12). Our results in relation to seed set in interspecific crosses between eggplant and $S$. gilo, $S$. indicum, $S$. mammosum, $S$. torvum and $S$. xanthocarpum are in partial to complete agreement with the results of Rajasekaran $(15,16)$, Nasrallah and $\operatorname{Hopp}(11)$ and McCammon and Honma (9). Rajasekaran(15) and Nishio et al.
(12) reported that $S$. indicum, as the seed parent only, was compatible to eggplant. But in our investigations eggplant 'Senryo 2 gou' as the seed parent also produced viable seeds with this species (Fig. 1 and Table 3). Fruit and seed setting ability of this cultivar indicated rather wide range of crossability. The conflicting results of interspecific compatibility might be due to genotypic difference of the material within and between species used by different authors. As the pollen parent both of the eggplant cultivars showed higher crossability than as the seed parent indicating some sort of cytoplasmic regulation on the success of interspecific crosses.

To overcome the barriers pertaining to prefertilization incompatibility intraovarian pollination or in vitro fertilization may bring success. In some cases post-fertilization incompatibility are resulted into seed abortion as it was observed in the combinations of $S$. melongena, $S$. indicum and S. torvum. To overcome such incompatibility, excised premature embryo, ovule or ovary culture in vitro may be appropriate. For the most difficult but important combinations, somatic hybridization through protoplast fusion is the last tool to get the hybrid. 


\section{Literature Cited}

1. AnONymous. 1970. Ten years of Citrus and Vegetable Seed Research Center. p. 8-12. Hort. Divn., BARI, Joydebpur, Bangladesh.

2. BAKSH, S. 1970. Cytological studies on the $\mathrm{F}_{1}$ hybrid $S$. incanum L. $\times S$. melongena $\mathrm{L}$. variety 'Giant of Banarash'. Euphytica 28: 793-800.

3. Chichiricco, G. and M. G. CAIOlA. 1984. Crocus sativus pollen tube growth in intraand interspecific pollinations. Cariologia 37: 115-125.

4. KAhN, T. L. and D. A. DeMason. 1986. A quantitative and structural comparison of citrus pollen tube development in cross compatible and self incompatible gynoecia. Can. J. Bot. 64: 2548-2555.

5. KhAN, A. N. A. 1974. Studies on Pseudomonas solanacearum E.F. Smith causing wilt of brinjal, potato and tomato in Mysore state. Mysore J. Agr. Sci. 8: 477-478.

6. KHAN, R., G. R. RAO and S. BAKSH. 1978. Cytogenetics of $S$. integrifolium and its possible use in eggplant breeding. Indian J. Genet. 38: $343-347$.

7. KHO, Y. O. and J. BAER. 1968. Observing pollen tubes by means of fluorescence. Euphytica 17: 298-302.

8. Ludilov, V. A. 1972. On the crossability of $S$. melongena and $S$. integrifolium (Poir). Pl. Breed. Abstr. 43: 4020 (Abstr.).

9. MCCAMMON, R. K. and S. HoNMA. 1983. Morphological and cytogenetic analysis of an interspecific hybrid eggplant Solanum melongena $\times S$. torvum. HortScience 18: 894-895.

10. MochIZUKI, H. and K. YAMAKAWA. 1979. Resistance of selected eggplant cultivars and related wild Solanum species to bacterial wilt (Pseudomonas solanacearum). Bull. Veg. \& Ornam. Crops Res. Stn. Ser. A No. 6: 1-10. (In Japanese with English summary)
11. Nasrallah, M. E. and R. J. Hopp. 1963. Interspecific cross between $S$. melongena $\mathrm{L}$. (eggplant) and related Solanum species. Proc. Amer. Soc. Hort. Sci. 83: 571-574.

12. Nishio, T., H. MOCHIZUKI and K. YAMAKAWA. 1984. Interspecific cross of eggplants and related species. Bull. Veg. \& Ornam. Crops Res. Stn. Ser. A No. 12: 57-64. (In Japanese with English summary)

13. OMIDIJI, M.O. 1975. Interspecific hybridization in the non-tuberous Solanum species. Euphytica 24: 341-353.

14. Pimienta, E., V. S. Polito and D. E. KESTER. 1983. Pollen tube growth in crossand self pollinated "Nonpareil" almond. J. Amer. Soc. Hort. Sci. 108: 643-647.

15. RAJASEKARAN, S. 1970. Cytogenetic studies of the $\mathrm{F}_{1}$ hybrid $S$. indicum L. $\times S$. melongena L. and its amphidiploid. Euphytica 19: 217224.

16. RAJASEKARAN, S. 1971. Cytological studies on the $F_{1}$ hybrid (Solanum xanthocarpum Scard and Wendl. $\times S$. melongena L.) and its amphidiploid. Cariologia 24: 261-267.

17. TATEBE, T. 1936. Genetic and cytological studies on the $F_{1}$ hybrid of scarlet or tomato eggplant ( $S$. integrifolium Poir.) $\times$ eggplant (Solanum melongena L.). Bot. Mag. (Tokyo) 50: 457-462. (In Japanese with English resume)

18. VASIL, I. K. 1987. Physiology and culture of pollen. p. 127-165. In: K. L. Giles and J. Prakash (eds.) Pollen: Cytology and Development. Review of Cytology. Vol. 107. Acad. Press. Inc., Orlondo. Florida.

19. YAMAKAWA, K. and H. MochIzUKI. 1979. Nature and inheritance of Fusarium wilt resistance in eggplant cultivars and wild Solanum species. Bull. Veg. \& Ornam. Crops Res. Stn. Ser. A No. 6: 19-27. (In Japanese with English summary) 


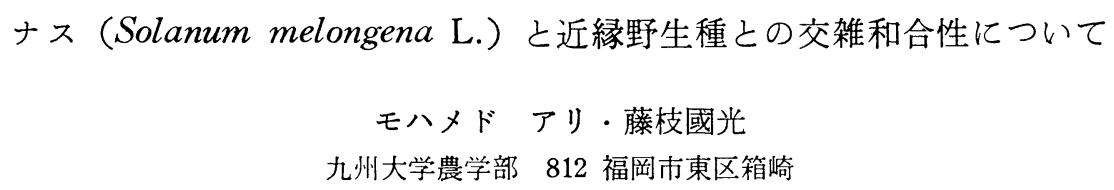

\section{摘 要}

ナスと近縁野生種とを交配し，花粉管の伸長行動と種 子稔性について調べた.

S. gilo, S. insanum, S. integrifolium とナスとは 高い交雑和合性が認められた，S. indicum は“千両 2 号’とは正逆交雑で多くのしいなをえたが，'Uttara'と は種子親の場合に $50 \%$ の稔実種子をえた. S. surattense とS. xanthocarpum は ‘千両 2 号”が花粉親の場合に 少量の発芽力のある種子をえた． S. mammosum の花 粉管は ‘千両 2 号’ の花柱内を正常に生長したが，この
組合せでは雑種種子はえられず, 単為結果にとどまった。 なお‘千両 2 号’ は 8 つの近縁種の花粉で単為結果を生 じたが，'Uttara'はそれらを花粉親にした交配では全く 着果しなかった.

交雑不和合の組合せでは, 花粉の不発芽または発芽不 良, 花粉管の生長遅延・子房到達前の生長停止・微弱な 䖝光発色, カロースプラグの不規則な沈積・分布・大き さ, 花粉管先端の肥厚や分岐などが, 単独あるいは複合 して観察された. 